ISSN 0103-5150

Fisioter. Mov., Curitiba, v. 29, n. 1, p. 137-46, Jan./Mar. 2016

Licenciado sob uma Licença Creative Commons

DOI: http://dx.doi.org.10.1590/0103-5150.029.001.A015

\title{
Prevalence of back pain among high school students in a municipality in southern Brazil
}

\author{
Prevalência de dor nas costas em escolares do \\ ensino médio em uma cidade no sul do Brasil
}

\author{
Cíntia Detsch Fonseca ${ }^{[a]}$, Cláudia Tarragô Candotti ${ }^{[a]}$, Matias Noll ${ }^{[a]}$, Anna Maria Hecker Luz ${ }^{[b]}$, \\ Antônio Cardoso dos Santos ${ }^{[a]}$, Carlos Otávio Corso ${ }^{[a] *}$ \\ [a] Universidade Federal do Rio Grande do Sul, (UFRGS), Porto Alegre, RS, Brazil \\ [b] Universidade Vale do Rio dos Sinos, (UNISINOS), Porto Alegre, RS, Brazil
}

\begin{abstract}
Objective: To estimate the prevalence of back pain in adolescent girls, and determine whether this pain is associated with socioeconomic, demographic, anthropometric, and behavioral factors. Methods: This was an epidemiological survey with a representative sample of 495 female high school students, aged 14 to 18 years, in the municipality of São Leopoldo in the southern Brazilian state of Rio Grande do Sul. Data were collected through a self-administered questionnaire with closed, standardized, coded, and tested questions. Bivariate analysis included the chi-square test $(\mathrm{x} 2)$ and calculation of prevalence ratios $(\alpha<0.05)$. Results: The prevalence of back pain was 75.2\%. The thoracic-lumbar (30.4\%) and lumbar (27.7\%) regions of the spine were most affected. Among the students with pain, $60.5 \%$ reported the severity of their pain to be moderate to severe, and $21.2 \%$ reported that the pain prevented them from performing activities of daily
\end{abstract}

* CDF: grad, e-mail: cintiadetsch@gmail.com CTC: grad, e-mail: claudia.candotti@ufrgs.br MN: grad, e-mail: matiasnoll@yahoo.com.br AMHL: grad,e-mail: familialuz@cpovo.net ACS: grad, e-mail: acarsantos@gmail.com COC: grad, e-mail: corso@portoweb.com.br 
living. Regarding associated factors, the pain was more prevalent in overweight/obese students $(\mathrm{RP}=1.246$, 95\% CI: 1.137 to 1.366), who reported carrying a heavy school backpack/bag (PR $=1.187,95 \%$ CI: 1.073 to 1.314) and those who had incorrect posture when picking up objects from the floor (PR $=1.138,95 \% \mathrm{CI}$ : 1.031 to 1.256). Conclusions: There was a high prevalence of back pain associated with body mass index, reported weight of the student's school backpack/bag, and posture when picking up objects from the floor.

Keywords: Back pain. Adolescent health. School health. Prevalence. Brazil.

\section{Resumo}

Objetivos: Estimar a prevalência de dor nas costas em adolescentes do sexo feminino no ano letivo e verificar se esta dor nas costas está associada com fatores socioeconômicos, demográficos, antropométricos e comportamentais. Métodos: Inquérito epidemiológico com amostra representativa de 495 estudantes do sexo feminino do ensino médio regular diurno, com idade de 14 a 18 anos, da cidade de São Leopoldo, RS, Brasil. Os dados foram coletados através de um questionário auto-aplicável composto por questões fechadas, padronizado, codificado e testado. A análise bivariada incluiu o teste do qui-quadrado (x2) e o cálculo das razões de prevalência $(\alpha<0,05)$. Resultados: A prevalência de dor nas costas foi de $75,2 \%$. As regiões mais acometidas foram dorso-lombar (30,4\%) e lombar (27,7\%). Entre as alunas com dor, 60,5\% apontaram uma intensidade de média a muita dor e 21,2\% relataram que a dor as impediu de realizar suas atividades normais do dia a dia. Em relação aos fatores associados, a dor foi mais prevalente nas alunas com sobrepeso/obesidade ( $R P=1,246$; IC95\%: 1,137 a 1,366), nas que relataram mochila/bolsa escolar pesadas ( $R P=1,187$; IC95\%: 1,073 a 1,314) e nas que adotavam uma postura incorreta ao pegar objetos do chão (RP = 1,138; IC95\%: 1,031 a 1,256). Conclusões: $A$ prevalência de dor nas costas foi alta e esteve associada com IMC, com o peso relatado da mochila/bolsa escolar e com a postura ao pegar objetos do chão.

Palavras-chave: Dor nas Costas. Saúde do Adolescente. Saúde Escolar. Prevalência. Brasil.

\section{Introduction}

The occurrence of back pain and postural changes considerably limits the active life of workers, and is responsible for the premature disability of many adults from activities of daily living (ADL) $(1,15)$. Back pain and postural changes can also be considered socioeconomic and public health problems, because the costs of diagnosis and treatment are high and lead to losses due to missed work time and early retirement (7).

In addition to being widely present in adults, back pain and postural changes manifest themselves in childhood and adolescence $(10,11,25,29)$. One recent cross-sectional study pointed out that the occurrence of musculoskeletal pain in two or more anatomical areas is high among young students (22). A high prevalence of back pain was also found in one study with 887 adolescent students, which found that $66 \%$ of those evaluated experienced this type of pain. Furthermore, back pain was significantly higher in girls than in boys (19).
Likewise, one cross-sectional study (25) that applied a questionnaire to 400 students aged 10 to 18 years in Kuwait found that the prevalence of pain in the lumbar spine increased with age. At 10 years, $31 \%$ of those evaluated reported pain in the lumbar spine, compared to $74 \%$ at 18 years of age. The authors of this study believe that this gradual increase in the occurrence of pain may be due to the increase and accumulation of weight overload on the spine (25). Based on this assumption, it has been speculated that low back pain in childhood is a predictive factor of low back pain in later life (18).

Back pain in young people may have multiple causative factors (26). Use of heavy backpacks and carrying these asymmetrically (16), sitting for long periods of time with poor posture(30), use of anatomically incorrect furniture (18), watching television for long periods of time, performing different ADL with incorrect posture (28), sleeping less than seven hours a day, smoking, obesity (22), and psychological factors such as depression and anxiety $(8,18)$ are some of the risk factors for onset of back pain in students. 
From the results of epidemiological studies demonstrating the high prevalence of back pain in students - considered a serious public health problem - and given that these data cannot be extrapolated for different regions due to various social, cultural, and environmental factors, studies for different regions of Latin America, more specifically southern Brazil, are justified. Likewise, knowing that students that experience low back pain in childhood have a higher risk of suffering from this ailment in later life (29), all forms of intervention via educational and preventive programs are relevant. Yet in order for these preventive programs to be successfully deployed, studies that describe the characteristics of the target population are necessary. This study aimed to estimate the prevalence of back pain in adolescent girls, and to determine whether this pain is associated with socioeconomic, demographic, anthropometric, and behavioral factors.

\section{Materials and methods}

This was an epidemiological survey undertaken with students, aged 14 to 18 years, in high schools in the city of São Leopoldo in the southern state of Rio Grande do Sul, Brazil. The sample was calculated using the software Epi Info 6.0, and based on a population of 9.721 female students in this age group (2). The following data were used to calculate the sample size (12): prevalence of 30\%, confidence level 95\%, sampling error of $5 \%$, design effect of 1.5 , and $10 \%$ losses or refusals. Five hundred fifteen adolescents from all of the regular high schools of São Leopoldo with daytime hours ( 10 public and 10 private) were invited to participate in the study; of these, 495 accepted (percentage of losses and refusals was equivalent to $4 \%$, not including selection bias).

The selection of the sample was proportional to the number of students in each school, ensuring each sampling unit the same probability of belonging to the sample. At each school, a single random drawing was performed of the total number of students aged 14 to 18 and enrolled in the third quarter of the school daytime session.

The study was approved by the Research Ethics Committee of the Universidade do Vale do Rio dos Sinos, under Opinion no. 04/025, and adhered to Resolution 466/12 of the National Health Council. The students selected received a free and informed consent form to read to help them to decide whether to participate, which was signed by a parent or guardian.

\section{Data collection and analysis}

Authorization to undertake the study was obtained from the Municipal Secretary of Education of São Leopoldo. Following approval, every high school in the municipality with daytime sessions was invited to participate in the study at a meeting with the leadership of the institutions, in which the research objectives and data collection procedures were explained. Once the schools agreed to participate, a date for application of the questionnaires was scheduled. The questionnaires were applied individually, in a location designated by the school that was prepared to carry out data collection. Initially, the study objectives were explained and directions were provided as to how the questionnaire should be filled out. Participants filled out the questionnaire individually and this took about 25 minutes. The researcher of the study remained at the location the entire time, and collected the questionnaires as they were completed.

The questionnaire was developed by Detsch et al. (11), and was self-applicable, standardized, coded, and tested, and was composed of closed questions on back pain and social, economic, demographic, and behavioral variables. For the question about location of back pain, a drawing was used to help the students, who were instructed to mark the most affected region (cervical, thoracic, thoracic-lumbar, or lumbar). On questions related to posture when watching television, using the computer, and picking up objects from the ground, drawings were presented of correct and incorrect postures, and the students marked the position that best corresponded to their postures in these ADL. After data collection, the variables were grouped for association analysis.

Measurement of anthropometric variables (height and body mass) was performed to calculate body mass index (BMI). The girls' height was measured using an anthropometer mounted on a wall and adjusted with a level to avoid poor positioning, and the values were measured in centimeters. The measurement of body mass was performed using a digital scale (Rib Plenna brand), calibrated with a standardized weight of $5 \mathrm{~kg}$ after five students were weighed. 
For analysis, BMI was grouped according to the classification by Cole et al.(9)

To identify typos and correct these, data entry was performed by two independent typists using the software program Epi Info 6.0. The software Statistical Package for the Social Sciences (SPSS) version 20.0 was used for statistical analysis.

Bivariate analysis included the chi-squared test $\left(\mathrm{x}^{2}\right)$ and calculation of prevalence ratios $(\alpha<0.05)$, with pain as the dependent variable. Independent variables were: type of school and level of education of parents and/or guardians (socio-economic variables), age (demographic variable), height and BMI (anthropometric variables), postures adopted in ADL, exposure time of some postures, and physical activity (behavioral variables).

Logistic regression was performed to check for bias of confusion between statistically significant variables in the bivariate analysis. Variables that had a significance of $p<0.20$ were included in the multivariate model.

\section{Results}

The prevalence of back pain during the academic year among the students evaluated was $75.2 \%$ ( $\mathrm{n}=$ 372).

Among those students with back pain ( $\mathrm{n}=372$ ), the region of the vertebral column where the pain was strongest (the students were instructed to indicate a single choice) were as follows: $21 \%(\mathrm{n}=78)$ cervical region, $21 \%(n=78)$ thoracic region, $30.4 \%(n=113)$ thoracic-lumbar region, and $27.7 \%(\mathrm{n}=103)$ lumbar region. The students' subjective self-assessments of pain intensity were: $39.5 \%(n=147)$ mild pain, $54.6 \%$ $(\mathrm{n}=203)$ moderate pain, and $5.9 \%(\mathrm{n}=22)$ severe pain. As for frequency of pain, $81.5 \%(n=303)$ of the students responded that the pain frequency was one time per week, $11.8 \%(n=44)$ between two and three times per week, and 6.7\% $(n=25)$ more than four times per week. According to the results, of all students affected by back pain, $21.2 \%(n=79)$ experienced pain that prevented them from performing ADL.

Analysis of the association between pain intensity and impediment to undertaking ADL due to pain confirmed that there is an association between these variables $(p<0.01)$. Hindrance of ADL was four times greater among students who had moderate to severe pain, compared with students who had mild pain $(\mathrm{RP}=4.039$; CI 95\%: 2.212 - 7.375). An association was also found between weekly frequency of pain and impediment to perform ADL due to pain ( $\mathrm{p}<0.01$ ). Students who had two or more episodes of pain per week were two times more likely to be impeded from performing ADL in comparison with students who reported up to one episode of pain per week $(\mathrm{RP}=2.280$; CI 95\%: 1.552 - 3.349).

The results of the socioeconomic, demographic, anthropometric, and behavioral characteristics are presented in Tables 1 and 2 .

In the bivariate analysis, back pain was associated with BMI, reported weight of school backpack, bag, or purse, sitting posture in the classroom, time spent watching television, and posture when picking up objects from the ground (Tables 1 and 2).

Overweight and/or obese students had a higher prevalence of pain than students with normal BMI. Students who considered their school backpacks or bags to be heavy had a higher prevalence of back pain compared with students who did not consider their school backpacks or bags to be heavy.

Students who adopted inadequate postures in class (body leaning over desk or sitting on the edge of the chair, with one foot on the chair, or body drooping into the chair) had a higher prevalence of pain compared with those students who adopted proper posture in the classroom (back well supported in the chair and feet flat on the floor).

Students who watched television more than 10 hours per week had a higher prevalence of pain compared to those who did not watch television or who watched fewer than 10 hours per week.

Students who reported picking objects up off the floor with incorrect posture (with trunk flexion without bending the knees) had a higher prevalence of back pain compared with students who adopted a correct posture during this action (bending the knees, keeping the back straight).

In the multivariate analysis, back pain continued to be associated with BMI ( $p=0.006)$, selfreported weight of school backpack, bag, or purse ( $p=0.019)$, and posture picking up objects from the ground $(\mathrm{p}=0.013)$. After multivariate analysis, the variables "posture sitting in classroom" and "time watching television" had no association with back pain ( $p=0.149$ and $p=0.111$, respectively) (Table 3). 
Table 1 - Prevalence of back pain and socioeconomic, demographic and anthropometric variables in female students aged 14 to 18 years, São Leopoldo, Rio Grande do Sul, Brazil, 2004

\begin{tabular}{|c|c|c|c|c|}
\hline Variables & $N(\%)$ & $\begin{array}{l}\text { Pain } \\
\mathrm{N}(\%)\end{array}$ & $\mathrm{p}^{\mathrm{a}}$ & Ratio of prevalence (C195\%) \\
\hline \multicolumn{5}{|l|}{ Socioeconomic } \\
\hline \multicolumn{5}{|l|}{ Type of school } \\
\hline Private & $134(27.1)$ & 95 (70.9) & & 1.00 \\
\hline Public & 361 (72.9) & 277 (76.7) & 0.182 & 1.082 (0.958 to 1.223$)$ \\
\hline \multicolumn{5}{|c|}{ Education of responsible female ${ }^{c}$} \\
\hline College or graduate degree & $102(21.4)$ & $76(74.5)$ & & 1.00 \\
\hline High School & $145(30.5)$ & $106(73.1)$ & 0.805 & 0.981 (0.844 to 1.140$)$ \\
\hline Basic education & $229(48.1)$ & 177 (77.3) & 0.582 & 1.037 (0.908 to 1.185$)$ \\
\hline \multicolumn{5}{|c|}{ Education of responsible male ${ }^{c}$} \\
\hline Up to college or graduate & $111(23.8)$ & $75(67.6)$ & & 1.00 \\
\hline High School & $146(31.3)$ & $114(78.1)$ & 0.058 & 1.156 (0.990 to 1.349$)$ \\
\hline Basic education & $209(44.9)$ & $160(76.6)$ & 0.083 & $1.133(0.976$ to 1.315$)$ \\
\hline \multicolumn{5}{|l|}{ Demographics } \\
\hline \multicolumn{5}{|l|}{ Age group (years) } \\
\hline 19 to 15 years & $181(36.6)$ & $136(75.1)$ & & 1.00 \\
\hline 16 years & $176(35.5)$ & $133(75.6)$ & 0.925 & 1.006 (0.893 to 1.132$)$ \\
\hline 17 to 18 years & $138(27.9)$ & $103(74.6)$ & 0.919 & 0.993 (0.874 to 1.129$)$ \\
\hline \multicolumn{5}{|l|}{ Anthropometric } \\
\hline \multicolumn{5}{|l|}{ Height (meters) } \\
\hline 1.46 to $1.65 \mathrm{~m}$ & $360(72.7)$ & $266(73.9)$ & & 1.00 \\
\hline 1.46 to $1.82 \mathrm{~m}$ & $135(27.3)$ & $106(78.5)$ & 0.288 & 1.063 (0.954 to 1.183$)$ \\
\hline \multicolumn{5}{|l|}{ Body mass index (BMI) } \\
\hline Normal & 387 (78.2) & $276(71.3)$ & & 1.00 \\
\hline Overweight/obesity & $108(21.8)$ & 96 (88.9) & $0.000^{\mathrm{b}}$ & 1.246 (1.137 to 1.366$)$ \\
\hline
\end{tabular}

Note: aBivariate analysis; Chi-square test

${ }^{b}$ Statistically significant association $(p<0.05)$

'Only for the students to which the variable applies 
Table 2 - Prevalence of back pain and socioeconomic, demographic and anthropometric variables in female students aged 14 to 18 years, São Leopoldo, Rio Grande do Sul, Brazil, 2004

\begin{tabular}{|c|c|c|c|c|}
\hline Variables & $N(\%)$ & $\begin{array}{l}\text { Pain } \\
\mathrm{N}(\%)\end{array}$ & $\mathrm{p}^{\mathrm{a}}$ & Ratio of prevalence (C195\%) \\
\hline \multicolumn{5}{|l|}{ Behavioral } \\
\hline \multicolumn{5}{|l|}{ Posture with purse or backpackc } \\
\hline $\begin{array}{l}\text { Correct (wearing two handles or } \\
\text { through) }\end{array}$ & $273(55.7)$ & $205(75.1)$ & & 1.00 \\
\hline Incorrect (hanging on one shoulder) & $217(44.3)$ & $163(75.1)$ & 0.995 & 1.00 (0.903 to 1.108$)$ \\
\hline \multicolumn{5}{|l|}{$\begin{array}{l}\text { Reported weight of the bag/ } \\
\text { backpack/school bagc }\end{array}$} \\
\hline Not heavy & $259(52.5)$ & $179(69.1)$ & & 1.00 \\
\hline Heavy & $234(47.5)$ & $192(82.1)$ & $0.001^{b}$ & 1.187 (1.073 to 1.314$)$ \\
\hline \multicolumn{5}{|l|}{ Posture in the classroom } \\
\hline Correct (feet and back supported) & $50(10.1)$ & $29(58.0)$ & & 1.00 \\
\hline Incorrect (other) & $445(89.9)$ & $343(77.1)$ & $0.003^{b}$ & 1.329 (1.044 to 1.692$)$ \\
\hline \multicolumn{5}{|l|}{ Posture in the classroom } \\
\hline Table and chair & $484(97.8)$ & $365(75.4)$ & & 1.00 \\
\hline Chair with arm & $11(2.2)$ & $7(63.6)$ & 0.478 & 0.844 (0.538 to 1.323$)$ \\
\hline \multicolumn{5}{|l|}{ Posture while watching television } \\
\hline Correct (feet and back supported) & $36(7.4)$ & $25(69.4)$ & & 1.00 \\
\hline Incorrect (other) & $453(92.6)$ & $343(75.7)$ & 0.401 & 1.090 (0.873 to 1.363$)$ \\
\hline \multicolumn{5}{|l|}{ Hours watching television per week } \\
\hline Zero to 10 & $334(67.5)$ & $239(71.6)$ & & 1.00 \\
\hline More than 10 & $161(32.5)$ & $133(82.6)$ & $0.008^{b}$ & 1.154 (1.047 to 1.273$)$ \\
\hline \multicolumn{5}{|l|}{ Posture when using computer } \\
\hline Correct (feet and back supported) & $111(27.5)$ & $76(68.5)$ & & 1.00 \\
\hline Incorrect (other) & $292(72.5)$ & $226(77.4)$ & 0.065 & 1.130 (0.982 to 1.301$)$ \\
\hline \multicolumn{5}{|l|}{ Weekly hours of computer use } \\
\hline Zero to eight & $434(87.7)$ & $323(74.4)$ & & 1.00 \\
\hline More than eight & $61(12.3)$ & $49(80.3)$ & 0.318 & 1.079 (0.942 to 1.236$)$ \\
\hline \multicolumn{5}{|l|}{ Reading or studying in bed } \\
\hline No & $140(28.3)$ & $97(69.3)$ & & 1.00 \\
\hline Yes & $355(71.7)$ & $275(77.5)$ & 0.058 & 1.118 (0.988 to 1.265$)$ \\
\hline \multicolumn{5}{|l|}{$\begin{array}{l}\text { Posture when picking up objects } \\
\text { from the floor }\end{array}$} \\
\hline Correct (knee flexion) & $326(65.9)$ & $234(71.8)$ & & 1.00 \\
\hline Incorrect (spine flexed) & $169(34.1)$ & $138(81.7)$ & $0.016^{b}$ & 1.138 (1.031 to 1.256$)$ \\
\hline \multicolumn{5}{|l|}{ Use of high-heeled shoes } \\
\hline $\begin{array}{l}\text { Does not use or uses up to two } \\
\text { times per week }\end{array}$ & $360(72.7)$ & $268(74.4)$ & & 1.00 \\
\hline Uses three or more times per week & $135(27.3)$ & $104(77.0)$ & 0.552 & 1.035 (0.927 to 1.155$)$ \\
\hline
\end{tabular}


Table 2 - Prevalence of back pain and socioeconomic, demographic and anthropometric variables in female students aged 14 to 18 years, São Leopoldo, Rio Grande do Sul, Brazil, 2004

\begin{tabular}{|c|c|c|c|c|}
\hline Variables & $N(\%)$ & $\begin{array}{l}\text { Pain } \\
N(\%)\end{array}$ & $\mathrm{p}^{\mathrm{a}}$ & Ratio of prevalence (C195\%) \\
\hline \multicolumn{5}{|l|}{ Posture while sleeping } \\
\hline $\begin{array}{l}\text { Correct (on side or on back with } \\
\text { pillow under knees) }\end{array}$ & $218(44.0)$ & $158(72.5)$ & & 1.00 \\
\hline $\begin{array}{l}\text { Incorrect (on stomach or back } \\
\text { without pillow under knees) }\end{array}$ & $277(56.0)$ & $214(77.3)$ & 0.222 & 1.066 (0.961 to 1.183$)$ \\
\hline \multicolumn{5}{|l|}{ Physical exercise } \\
\hline Yes & $390(78.8)$ & $291(74.6)$ & & 1.00 \\
\hline No & $105(21.2)$ & 81 (77.1) & 0.595 & 1.034 (0.918 to 1.165$)$ \\
\hline \multicolumn{5}{|l|}{$\begin{array}{l}\text { Practice competitive } \\
\text { physical exercisec }\end{array}$} \\
\hline No & $308(78.8)$ & $230(74.7)$ & & 1.00 \\
\hline Yes & 83 (21.2) & $62(74.7)$ & 0.997 & 1.00 (0.869 to 1.152$)$ \\
\hline \multicolumn{5}{|l|}{ Hours of exercise per weekc } \\
\hline Four or more hours per week & $99(25.3)$ & $74(74.7)$ & & 1.00 \\
\hline Up to three hours per week & $292(74.7)$ & $218(74.7)$ & 0.986 & 0.999 (0.875 to 1.140$)$ \\
\hline
\end{tabular}

Note: aBivariate analysis; Chi-square test

'Statistically significant association $(p<0.05)$

'Only for the students to which the variable applies

Table 3 - Multivariate analysis among the statistically significant variables in the bivariate analysis $(\mathrm{p}<0.20)$

\begin{tabular}{|c|c|c|}
\hline Variables & OR (CI95\%) & $\mathrm{p}^{\mathrm{a}}$ \\
\hline Type of school & $0.856(0.473-1.551)$ & 0.608 \\
\hline \multicolumn{3}{|l|}{$\begin{array}{l}\text { Education of } \\
\text { responsible male }^{c}\end{array}$} \\
\hline $\begin{array}{l}\text { Up to college or } \\
\text { graduate level }\end{array}$ & & 0.160 \\
\hline High school & $1.640(0.836-3.217)$ & 0.150 \\
\hline Basic education & $0.872(0.466-1.630)$ & 0.667 \\
\hline BMI & $0.321(0.143-0.719)$ & $0.006^{b}$ \\
\hline $\begin{array}{l}\text { Reported weight of the } \\
\text { school bag/backpack/ } \\
\text { purse }\end{array}$ & $0.543(0.326-0.905)$ & $0.019^{b}$ \\
\hline Posture in the classroom & $0.560(0.255-1.230)$ & 0.149 \\
\hline Time watching television & $0.628(0.354-1.114)$ & 0.111 \\
\hline $\begin{array}{l}\text { Posture when using } \\
\text { computer }\end{array}$ & $0.888(0.504-1.567)$ & 0.682 \\
\hline Reading or studying in bed & $0.699(0.410-1.192)$ & 0.188 \\
\hline $\begin{array}{l}\text { Posture when picking up } \\
\text { objects from the floor }\end{array}$ & $0.485(0.275-0.856)$ & $0.013^{b}$ \\
\hline
\end{tabular}

Note: anodel of logistical regression by the method of entry

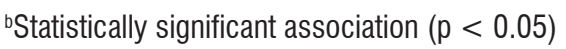

\section{Discussion}

This study found a high prevalence of back pain in female high school students, because $75.2 \%$ of the students that participated in the study reported pain in some region of their back during the school year, with the most affected regions being the thoraciclumbar $(30.4 \%)$ and lumbar $(27.7 \%)$.

It is possible that this high prevalence is because this study evaluated not only the prevalence of low back pain, but of other regions of the spine as well, and assessed prevalence of pain during the academic year among only female students. Other studies also indicate a high prevalence of back pain among students, especially in the lumbar region. One cross-sectional study of 833 adolescents of both sexes (mean age 14, 17 years) in a private school in São Paulo included 791 students in the study, and found a prevalence of back pain of 23\% (31).

Another cross-sectional study (19) conducted with 887 adolescents aged 12 to 16 years in Spain, and which included a total of 849 adolescents, had a prevalence of back pain of $66 \%$ in the senior year, and $51 \%$ of these students reported having pain the 
week before the survey. The results indicated that $41.78 \%$ reported pain in the lumbar region, $29.64 \%$ in the thoracic region, and $28.57 \%$ in the thoraciclumbar region (19). It is notable that both the study by Martinez-Crespo et al. (19) and this study evaluated pain in different regions of the thoracic spine, but not pain in the cervical region.

In Japan, one cross-sectional study (23) conducted with 43.630 students (children and adolescents) evaluated both the presence of pain at the time the questionnaire was applied and the presence of back pain in the past. Of the total evaluated, 34.423 questionnaires were submitted to the researchers. The results showed that $10.2 \%$ of respondents had pain in the lumbar region of the spine at the time of data collection, and $28.8 \%$ had a history of lumbar pain. Furthermore, $66.7 \%$ reported that the pain lasted less than a week, and $86.1 \%$ less than a month. The pain recurred in $60.5 \%$ of students. Of those students with a history of pain in the lumbar region, $81.9 \%$ reported having Level 1 pain (without limitation of activities), $13.9 \%$ Level 2 pain (need to abstain from sports and physical activities), and $4.2 \%$ Level 3 pain (need to be absent from school). The severity of pain was greater in students whose duration of low back pain was more than one month, compared to those whose pain lasted less than one month, and was also higher in students with recurrent pain (23).

Regarding the intensity of pain in this study more than half of the 372 students affected by pain $(60.5 \%)$ reported moderate or severe pain, and more than onefifth $(21.2 \%)$ of these indicated that the pain prevented them from performing ADL. These are troubling data that should be carefully monitored, because they show that, even at this young age, back pain has an influence on the lives of girls that suffer from it.

In relation to factors associated with back pain in students in São Leopoldo, limitations included not measuring the weight of the backpack or school bag, because this information was self-reported by the students. In addition, the researchers did not establish a relationship of cause and effect due to the type of study design, in which the predictor and outcome variables were obtained at the same time. It should also be noted that care should be taken in relation to the applicability of the results of this study, which surveyed female teenagers between 14 and 18 years of age, to other populations with different characteristics.

After multivariate analysis, the predictor variables that were associated with back pain were BMI, the reported weight of the school backpack/bag, and posture when picking up objects from the ground (Table 3).

Overweight and/or obese students had a higher prevalence of pain than students with normal BMI. Similar results were found in a study that assessed students aged 15 and 16 years, which found that, in these girls, as well as in the schools of São Leopoldo, being overweight was associated with the presence of back pain (22).

The data from this study related to mode of transport of school supplies showed that $44.3 \%$ of those evaluated carried their school bags improperly. Similar results were found in a study that evaluated 1.263 students in Greece aged 12 to 18 years, which showed that $55 \%$ of students carried their backpack asymmetrically on their shoulders, and that this asymmetry was associated with increased pain in the lumbar region of the spine (17). Anther study verified the overwhelming preference of students to carry their backpacks assymmetrically: in the Netherlands, only $12.3 \%$ of children evaluated carried their backpacks properly (symmetrically), with both straps over the shoulders (27). This study found no association between mode of transport of school supplies and back pain; however, Neuschwander et al. (21) showed that, due to tilting torques in the long term, asymmetrical transport of school backpack and increased load in the backpack may be associated with increased back pain (21).

Contrary to the findings of this study, the high prevalence of poor posture when carrying a school backpack, although not associated with pain, in one survey of elementary school students of a school in the city of Dois Irmãos, also in Rio Grande do Sul, it was found that, regardless of school grade, the mode of transport most commonly used by the majority of students is a backpack with two straps on the back (75.9\% of the total number of students) supported symmetrically on both shoulders (6).

Although this study did not find an association between mode of transport of school supplies and back pain, it did find an association between reported weight of the backpack and pain. A similar result was found in a study by Haselgrove et al. (14), in which teenagers (of both sexes) who reported their backpacks as heavy also reported higher levels of back pain.

The results of this study also showed high percentages of poor posture when sitting in class 
(89.9\%), watching television $(92.6 \%)$, sleeping (56\%), and picking up objects from the ground (34.1\%); however, of these, only posture when picking up objects from the ground was associated with the presence of back pain.

In addition to these possible factors associated with back pain, time of exposure to these factors must also be taken into account. The time spent carrying the backpack, which was essentially the time the student takes to go from school to home and vice versa, is also responsible for the emergence of back pain (20). This finding indicates that, even when carrying school supplies with an appropriate weight and symmetrically, students may be harmed by carrying their bags for a long period of time.

This study did not indicate an association between back pain and physical exercise, competitive sports, and weekly hours of physical exercise, unlike results found by other researchers, which suggest that sports activities are a possible risk factor for the occurrence of low back pain, and could increase the risk of low back pain in childhood and adolescence (24), in addition to indicating that the practice of competitive sports for youth is also associated with low back pain (13).

Therefore, based on the results, and taking into consideration that bad posture habits begin in childhood and adolescence and can trigger back pain and even structural postural problems of the spine (11), it is understood that it is important in this stage of life to develop an awareness of the importance of maintaining proper posture during school activities.

An interesting option to mitigate problems related to bad posture in ADL is implementation of a school posture education program (PEP), which has the main objective to teach proper postures in ADL, thus avoiding postures that can damage the vertebral column (3 - 7). Nevertheless, to develop this type of program, support that is appropriate for students' realities are needed so that the program content is consistent with their needs. Therefore, further studies that seek to understand the various aspects involving back pain and body posture of students are needed.

In conclusion, the results of this study indicate a high prevalence of teenagers with back pain, and that this pain influences the ADL of these students and is associated with BMI, the weight of school bags/backpacks/notebooks, and with posture when picking up objects from the ground. Therefore, it is important that health and education professionals are alert to obesity, the weight of school backpacks/bags, and postures in ADL of children and teenagers, and that they work to prevent these aspects from leading to back pain in adulthood.

\section{References}

1. Alperovitch-Najenson D, Santo Y, Masharawi Y, KatzLeurer M, Ushvaev D, Kalichman L. Low back pain among professional bus drivers: ergonomic and occupational-psychosocial risk factors. Isr Med Assoc J. 2010;12(1):26-31.

2. Brasil, Ministério da Saúde. População residente, Rio Grande do Sul.[Cited in Oct. 1, 2004]. Available from: http://tabnet.datasus.gov.br/cgi/deftohtm.exe?ibge/ cnv/popRS.def.

3. Candotti CT, Macedo CH, Noll M, Freitas K. Escola de postura: uma metodologia adaptada aos pubescentes. Rev Mack Educ Fis Espor. 2010;9(2):91-100.

4. Candotti CT, Macedo CH, Noll M, Freitas K. Escola postural: uma metodologia adaptada para crianças. Rev Arq Movimento. 2009;5(2):34-49.

5. Candotti CT, Nunes SE, Noll M, Freitas K, Macedo CH. Efeitos de um programa de educação postural para crianças e adolescentes após oito meses do seu término. Rev Paul Pediatr. 2011;29(4):577-83.

6. Candotti CT, Roth E, Noll M. Assessment of weight and mode of transport of school material in highschool students. Rev Paul Pediatr. 2012;30(1):100-6.

7. Cardon G, De Clercq D, De Bourdeaudhuij I. Effects of back care education in elementary schoolchildren. Acta Paediatr. 2000;89(8):1010-7.

8. Cardoso Ribeiro C, Gómez Conesa A. Lower back pain: prevalence and preventive programs in childhood and adolescence. Rev Iberoam Fisioter Kinesiol. 2008;11(1):32-8.

9. Cole TJ, Bellizzi MC, Flegal KM, Dietz WH. Establishing a standard definition for child overweight and obesity worldwide: international survey. BMJ. 2000;320(7244):1-6.

10. Detsch C, Candotti CT. A incidência de desvios posturais em meninas de 6 a 17 anos da cidade de Novo Hamburgo. Movimento. 2001;7(15):43-56. 
11. Detsch C, Luz AMH, Candotti CT, Scotto de Oliveira D, Lazaron F, Guimarães LK, et al. Prevalência de alterações posturais em escolares do ensino médio em uma cidade no Sul do Brasil. Rev Panam Salud Publica. 2007;21(4):231-8.

12. Grimmer K, Williams M. Gender-age environmental associates of adolescent low back pain. Appl Ergon. 2000;31(4):343-60.

13. Hangai M, Kaneoka K, Okubo Y, Miyakawa S, Hinotsu $\mathrm{S}$, Mukai N, et al. Relationship between low back pain and competitive sports activities during youth. Am J Sports Med. 2010;38(4):791-6.

14. Haselgrove C, Straker L, Smith A, O'Sullivan P, Perry M, Sloan N. Perceived school bag load, duration of carriage, and method of transport to school are associated with spinal pain in adolescents: an observational study. Aust J Physiother. 2008;54(3):193-200.

15. Karahan A, Bayraktar N. Determination of the usage of body mechanics in clinical settings and the occurrence of low back pain in nurses. Int J Nurs Stud. 2004;41(1):67-75.

16. Kellis E, Emmanouilidou M. The effects of age and gender on the weight and use of schoolbags. Pediatr Phys Ther. 2010;22(1):17-25.

17. Korovessis P, Koureas G, Zacharatos S, Papazisis Z. Backpacks, back pain, sagittal spinal curves and trunk alignment in adolescents: a logistic and multinomial logistic analysis. Spine. 2005;30(2):247-55.

18. Limon S, Valinsky LJ, Ben-Shalom Y. Children at risk: risk factors for low back pain in the elementary school environment. Spine. 2004;29(6):697-702.

19. Martínez-Crespo G, Rodríguez-Piñero Durán M, LópezSalguero AI, Zarco-Periñan MJ, Ibáñez-Campos T, Echevarría-Ruiz de Vargas C. Dolor de espalda en adolescentes: prevalencia y factores asociados. Rehabilitación. 2009;43(2):72-80.

20. Negrini S, Carabalona R. Backpacks on! Schoolchildren's perceptions of load, associations with back pain and factors determining the load. Spine. 2002;27(2):187-95.

21. Neuschwander TB, Cutrone J, Macias BR, Cutrone S, Murthy G, Chambers H, et al. The effect of backpacks on the lumbar spine in children: a standing magnetic resonance imaging study. Spine. 2010;35(1):83-8.
22. Paananen MV, Taimela SP, Auvinen JP, Tammelin TH, Kantomaa MT, Ebeling HE, et al. Risk factors for persistence of multiple musculoskeletal pains in adolescence: a 2-year follow-up study. Eur J Pain. 2010;14(10):1026-32.

23. Sato T, Ito T, Hirano T, Morita O, Kikuchi R, Endo N, et al. Low back pain in childhood and adolescence: a cross-sectional study in Niigata City. Eur Spine J. 2008;17(11):1441-7.

24. Sato T, Ito T, Hirano T, Morita O, Kikuchi R, Endo N, et al. Low back pain in childhood and adolescence: assessment of sports activities. Eur Spine J. 2011;20(1):94-9.

25. Shehab DK, Al-Jarallah KF. Nonspecific low-back pain in Kuwaiti children and adolescents: associated factors. J Adolesc Health. 2005;36(1):32-5.

26. Siivola SM, Levoska S, Latvala K, Hoskio E, Vanharanta H, Keinänen-Kiukaanniemi S. Predictive factors for neck and shoulder pain: a longitudinal study in young adults. Spine. 2004;29(15):1662-9.

27. Van Gent C, Dols JJ, de Rover CM, Hira Sing RA, de Vet HC. The weight of schoolbags and the occurrence of neck, shoulder, and back pain in young adolescents. Spine. 2003;28(9):916-21.

28. Vanderthommen $M$, Defaweux $M$, Tomasella $M$, Crielaard JM. Le comportement gestuel du patient lombalgique fréquentant une école du dos: analyse préliminaire d'un test d'évaluation. Ann Readapt Med Phys. 1999;42(8):485-92.

29. Watson KD, Papageorgiou AC, Jones GT, Taylor S, Symmons DP, Silman AJ, et al. Low back pain in schoolchildren: occurrence and characteristics. Pain. 2002;97(1):87-92.

30. Womersley L, May S. Sitting posture of subjects with postural backache. J Manipulative Physiol Ther. 2006;29(3):213-8.

31. Zapata AL, Moraes AJ, Leone C, Doria-Filho U, Silva CA. Pain and musculoskeletal pain syndromes related to computer and video game use in adolescents. Eur J Pediatr. 2006;165(6):408-14.

Recebido: $19 / 09 / 2012$ Received: 09/19/2013

Aprovado: $17 / 07 / 2015$ Approved: 07/17/2015 